\title{
Reopening of tennis clubs and solutions for changing consumer habits in the COVID-19 era
}

\author{
Cem Tinaz $z^{a} \&$ Osman Emiroglu ${ }^{b}$ \\ ${ }^{\mathrm{a}}$ Istanbul Bilgi University, Istanbul, Turkey. ${ }^{\mathrm{b}}$ Near East University, Nicosia, North Cyprus.
}

\section{ABSTRACT}

This article offers a general overview of the drastic effects so far on sports industries of the Covid-19 pandemic and the attempts to contain its spread. It seeks specifically to give a framework that can support tennis clubs in their strategies for reopening, by utilizing a SWOT analysis as a basis to map clearly their current moment. It argues that all sports industries will emerge from this period radically transformed, that sports facilities such as tennis clubs need to alter their approach for this new era, and offers practical suggestions for how that might be achieved successfully.

\author{
Key words: COVID-19, re-opening, \\ clubs, consumers. \\ Received: 25 April 2020 \\ Accepted: 20 June 2020 \\ Corresponding author: Faculty of \\ Sports Science and Technology, \\ Istanbul Bilgi University, Istanbul, \\ Turkey. \\ Email: cemtinaz@gmail.com
}

\section{INTRODUCTION}

The outbreak of the Covid-19 pandemic is the defining global health crisis of our time, and it may be considered the most significant global challenge since World War Two. The pandemic has triggered the most severe economic recession in nearly a century, which may prove worse than the financial and economic crisis of 2008-09. The fast and dramatic changes due to Covid-19 are far from over, with great uncertainty still about the future. The degree to which individuals, organisations and institutions can adapt will determine whether societies manage to succeed in managing this crisis or continue to have more problems with adverse long-term effects. But what is undoubtedly clear is that the post-pandemic world will be different socially, economically, and health-wise. Health is guaranteed to be a dominating issue over the next few years, with experts anticipating significant shifts in the viewpoints and behaviour of individuals and organisations. Societies can expect significant changes in the following areas: trade, education, information technologies, tourism, social networks, faith, and international order (Sharfuddin, 2020). On the economic side, international financial institutions estimate an overall fall in global GDP between 2.4 to $2.8 \%$ this year (CNBC, 2020). As a result of the pandemic's economic impact, consumer income and expenditure are expected to decrease soon. However, increased spending is reported in some areas, with shifts in consumer behaviour towards new preferences expected to continue.

To fight with Covid-19, governments all around the world adopted a wide range of strict protective measures. These measures have included the closing of educational institutions, cancellation of mass social gatherings, national and international travel bans, restrictions on cultural and sporting events and finally, the imposition of lockdown condition on vast populations (Parnell et al., 2020). Of course, sports clubs and exercise facilities are among the organisations greatly affected. As contemporary sports consumption is highly dependent on live sporting events, these closures and cancellations have had broad disruptive effects. The Covid-19 crisis is somewhat different from previous global crises and has had real and tangible impacts on the sports industry. Some consolations might be that in certain countries where lockdowns and closures have seen a degree of normalisation, consumer interest in sports and exercise activities has been growing. The Covid-19 pandemic period has seen a move away from indoor sports facilities towards outdoor facilities, trails and other recreational areas. Similarly, online sports applications and also physical and mental awareness training sessions have all witnessed an increase in demand.

This article attempts to identify and discuss various effects of Covid-19 on tennis clubs and provide strategic suggestions to minimise the negative impacts of the virus on these enterprises.

\section{DISCUSSING THE IMPACT OF COVID-19 ON SPORT IN DIFFERENT ASPECTS}

Recently, sports organisations, including tennis clubs in many countries, have opened their doors and started with their operations under new normal regulations, involving a whole new set of restrictions and rules. Due to the changing behaviour of sports consumers and these new regulations, 
business will be conducted very differently. Teams must learn how to work together remotely, and organisations will have to find new ways of delivering their services from a distance. Clubs, coaches, medical staff and players should all be prepared for a challenging period (Mohr et al., 2020). In this section, we aim to identify some of the emerging changes in the consumption and delivery of sports.

One consequence of lockdown conditions has been that the demand for home fitness equipment such as yoga mats, free weights, resistance bands and exercise balls has sharply increased (Hammami et al., 2020).

Digital transformation of sports, though by far not a new topic, has accelerated dramatically during the time of the pandemic. The delivery of certain exercise forms such as Pilates, fitness and yoga are far more amenable to adaptation than tennis, with certain services moving quickly to online platforms. Recently, we witnessed a boom in YouTube workout channels, yoga classes via Zoom, Skype aerobics classes, etc.

Delivering sports through online platforms has many advantages, decreasing costs and time consumption. On the other hand, it is hard to say that consuming sports online offers a comparable experience to live gatherings. As a result, the social aspect of sports may gain more value in the future.

These are only some of the impacts which we expect to witness. However, the sports industry consists of many clusters, consisting of various products and services. The scope of this article is confined to providing tennis club management with a source of information for strategic planning during the Covid-19 era.

\section{SWOT ANALYSIS FOR TENNIS CLUBS TO EXAMINE THE} CURRENT CONDITIONS CORRECTLY

For this study, we chose to implement a SWOT analysis, which is a robust tool for strategy formulation and selection. However, it should be noted that this analysis is relative to our given context and certain factors might vary elsewhere.

\begin{tabular}{|c|c|}
\hline Strengths & Weaknesses \\
\hline $\begin{array}{l}\text { - Professionals who have } \\
\text { been waiting and planning } \\
\text { for a long time to work } \\
\text { - } \quad \begin{array}{l}\text { Increased consciousness } \\
\text { of members and club }\end{array} \\
\text { employees } \\
\text { - } \quad \text { Having time to plan } \\
\text { preparation process until } \\
\text { the club opens } \\
\text { - Panic phase has passed - } \\
\text { management capable of } \\
\text { dealing with crisis } \\
\text { competently } \\
\text { Having facilities with wide } \\
\text { open spaces, outdoor } \\
\text { courts } \\
\text { Trustworthy facilities } \\
\text { with high level of } \\
\text { competence in cleaning } \\
\text { and hygiene }\end{array}$ & 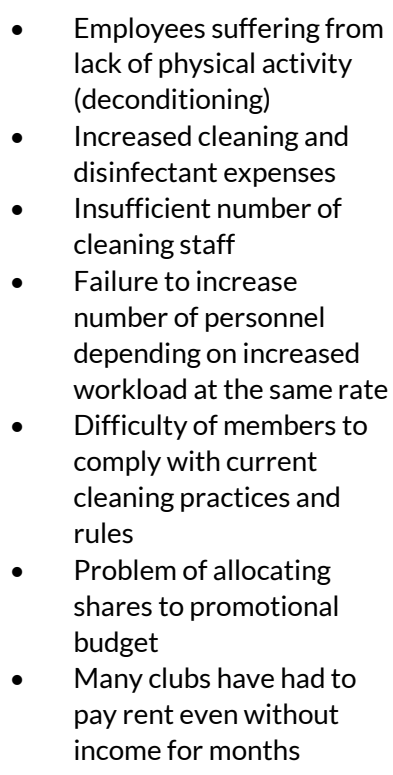 \\
\hline Opportunities & Threats \\
\hline $\begin{array}{l}\text { Desire of members } \\
\text { waiting for the opening of } \\
\text { facilities } \\
\text { Increasing importance of } \\
\text { preventive health and } \\
\text { need for physical exercise } \\
\text { Opportunity to apply } \\
\text { cleaning rules that could } \\
\text { not be applied previously } \\
\text { Relatively increased } \\
\text { negotiability of new } \\
\text { sports equipment } \\
\text { Individual training } \\
\text { sessions } \\
\text { Possibility of extra sales } \\
\text { during summer period } \\
\text { (relatively fewer sales in } \\
\text { an ordinary summer) } \\
\text { Hybrid member exercise } \\
\text { tracking systems } \\
\text { Availability of on-site } \\
\text { monitoring software for } \\
\text { distancing measures } \\
\text { which can track people } \\
\text { within club space } \\
\text { Increasing necessity and } \\
\text { possibilities of personnel } \\
\text { to improve their health } \\
\text { knowledge } \\
\text { Increased awareness of } \\
\text { elderly population on } \\
\text { positive effects of } \\
\text { exercise on health }\end{array}$ & 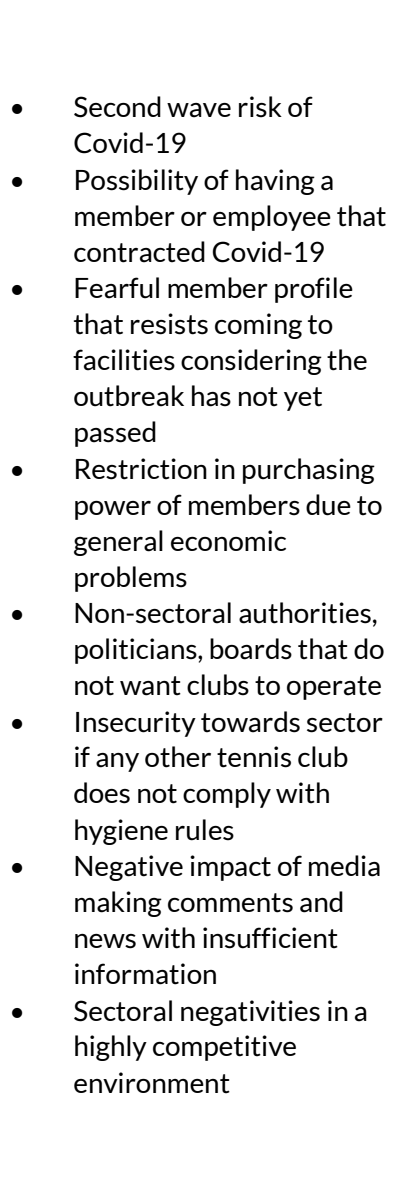 \\
\hline
\end{tabular}




\section{TASKS FOR TENNIS CLUBS AFTER THE OPENING}

As with all organisations, tennis clubs should build on their strengths and try to minimise their weaknesses. Especially during the Covid-19 era, tennis clubs have to maximise their response to opportunities and ultimately overcome threats. In the following section, we have aimed at creating a to-do list for this purpose.

First, members need to be informed about the practices and rules in the Covid-19 era. There should be daily evaluations about Covid-19 cleaning and hygiene applications, and continuous improvement of these applications through feedback. Continued promotion through social media and other platforms by sharing images and videos from facilities would inspire trust in members who are considering returning. Potential new or existing customers might be better persuaded by a personal phone call. Previous crowd group sessions (for example a tennis school for children) should be divided into smaller groups, with the number of sessions increased and campaigns made for individual training sessions. In-house team meetings should be held more frequently and in a knowledge-sharing manner so that negative situations are resolved with proactive methods before they occur. We suggest sharing plans for the future to ensure the continuity of members and keeping members informed of plans and changes. Evaluation, scoring and updating of the applications at regular intervals after the opening in the project management format are also recommended. Ensuring an insulated and infection-free environment is the most critical issue during this process, and management's task is to draw on all available resources to achieve this goal.

\section{CONCLUSION AND DISCUSSION}

There is no doubt that we are witnessing one of the most extraordinary and unprecedented periods in the modern world. But tennis clubs must convince their members to come back. Tennis clubs offer a means to health and wellness, and this is what people need. The only way that your members will come back is if they are assured that coming to you is still their best option. Clubs will reopen, and the world of sports will be active again. However, it is impossible to believe that we will see a return to how things were done before the pandemic. The world is verging on a new reality, and sports industries have to be transformed in this direction. These changes will leave tennis clubs with some complicated questions, centring on how to deliver quality services to customers that ensure their safety and inspire their confidence.

\section{REFERENCES}

CNBC (2020, Mar 10) How bad could it get? Economists predict how the coronavirus could hurt the global economy. Retrieved from https://www.cnbc.com/2020/03/10/coronavirusanalysts-cut-global-growth-forecasts-as-epidemicspreads.html

Hammami, A., Harrabi, B., Mohr, M., \& Krustrup, P. (2020). Physical activity and coronavirus disease 2019 (COVID19): specific recommendations for home-based physical training. Managing Sport and Leisure, https://doi.org/10.1080/23750472.2020.1757494.

Mohr, M., Nassis, G. P., Brito, J., Randers, M. B., Castagna, C., Parnell, D., \& Krustrup, P. (2020). Return to elite football after the COVID-19 lockdown. Managing Sport and Leisure, https://doi.org/10.1080/23750472.2020.1768635.

Parnell, D., Widdop, P., Bond, A., \& Wilson, R. (2020). COVID19, networks and sport. Managing Sport and Leisure, 1-7, https://doi.org/10.1080/23750472.2020.1750100

Sharfuddin, S. (2020.) The world after Covid-19. The Round Table, 109:3, 247-257, https://doi.org/10.1080/00358533.2020.1760498

RECOMMENDED ITF TENNIS ACADEMY CONTENT (CLICK BELOW)

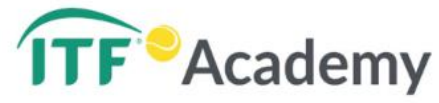

Copyright (c) 2020 Cem Tinaz \& Osman Emiroglu

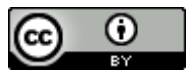

This text is under a Creative Commons BY 4.0 license

You are free to Share - copy and redistribute the material in any medium or format - and Adapt the content - remix, transform, and build upon the material for any purpose, even commercially under the following terms:

Attribution: You must give appropriate credit, provide a link to the license, and indicate if changes were made. You may do so in any reasonable manner, but not in any way that suggests the licensor endorses you or your use.

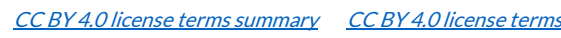

